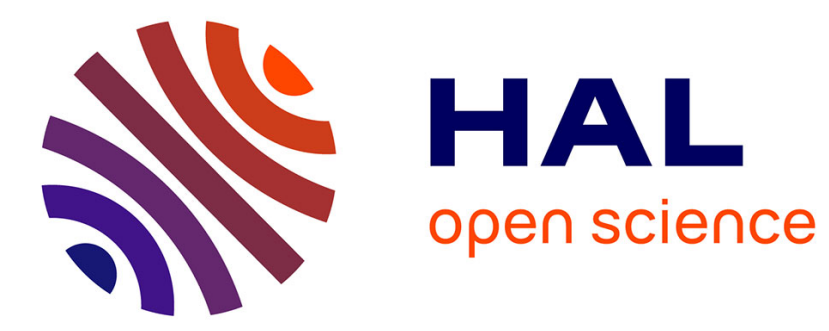

\title{
Markets Segmented by Regional-Origin Labelling with Quality Control
}

\author{
Roland Herrmann, Sven Anders, Stanley R. Thompson
}

\section{To cite this version:}

Roland Herrmann, Sven Anders, Stanley R. Thompson. Markets Segmented by RegionalOrigin Labelling with Quality Control. Applied Economics, 2009, 41 (03), pp.311-321. 10.1080/00036840601007237 . hal-00582032

\section{HAL Id: hal-00582032 \\ https://hal.science/hal-00582032}

Submitted on 1 Apr 2011

HAL is a multi-disciplinary open access archive for the deposit and dissemination of scientific research documents, whether they are published or not. The documents may come from teaching and research institutions in France or abroad, or from public or private research centers.
L'archive ouverte pluridisciplinaire HAL, est destinée au dépôt et à la diffusion de documents scientifiques de niveau recherche, publiés ou non, émanant des établissements d'enseignement et de recherche français ou étrangers, des laboratoires publics ou privés. 


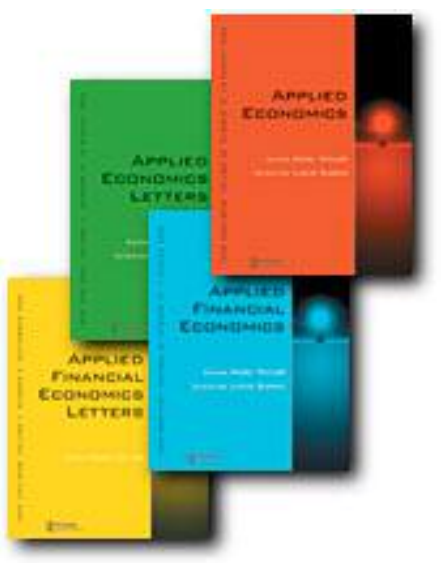

Markets Segmented by Regional-Origin Labelling with Quality Control

\begin{tabular}{|r|l|}
\hline Journal: & Applied Economics \\
\hline Manuscript ID: & APE-05-0705.R1 \\
\hline Journal Selection: & Applied Economics \\
\hline JEL Code: & $\begin{array}{l}\text { Q00 - General }<\text { Q0 - General }<\text { Q - Agricultural and Natural } \\
\text { Resource Economics, Q18 - Agricultural Policy|Food Policy }<\text { Q1 - } \\
\text { Agriculture }<\text { Q - Agricultural and Natural Resource Economics, Q17 } \\
\text { - Agriculture in International Trade < Q1 - Agriculture }<\text { Q }- \\
\text { Markets and Marketing|Cooperatives|Agribusiness }<\text { Q1 - } \\
\text { Agriculture }<\text { Q - Agricultural and Natural Resource Economics, Q12 } \\
\text { - Micro Analysis of Farm Firms, Farm Households, and Farm Input } \\
\text { Markets < Q1 - Agriculture < Q - Agricultural and Natural Resource } \\
\text { Economics }\end{array}$ \\
\hline Keywords: & $\begin{array}{l}\text { Regional-origin labelling, segmented markets, generic promotion, } \\
\text { Gepruefte Qualitaet - Bayern, economic welfare }\end{array}$ \\
\hline \hline
\end{tabular}

\section{s) ScholarONE" \\ Manuscript Central}




\section{Markets Segmented by Regional-Origin Labelling with Quality}

\section{Control}

\section{Introduction}

The protection of the regional origin of foods is a major part of the EU's quality policy in agriculture. According to Council Regulation No. 2081/1992, "the promotion of products having certain characteristics could be of considerable benefit to the rural economy, in particular to less-favored or remote areas, by improving the incomes of farmers and by retaining the rural population in these areas" (Commission of the EU 1992). When the guidelines for State aid for advertising of products were established in 2001 (Commission of the EU 2001), only the promotion of those agricultural products can be supported which are protected designations of origin (PDO) as outlined in Council Regulation No. 2081/92 (Art. 2, Council Regulation No. 2081/1992) ${ }^{1}$. This decision implies that regional-origin labelling has to be associated with a quality-control system that leads to a superior quality, if the program is to be subsidised by the government.

Generic promotion of agricultural products by EU member countries as well as regional marketing initiatives by federal states in line with these regulations have been widespread for years. However, despite the high - and possibly increasing value the EU addresses to the promotion of regional products, analytical work on the economic impacts of those initiatives is lacking. While the economic importance of regional-origin labelled products in consumer demand has been confirmed [BALLING

\footnotetext{
${ }^{1}$ There are two kinds of regional origin that are registered and protected under Council Regulation No. 2081/1992: (i) Protected Designation of Origin (PDO) and (ii) Protected Geographical Indication (PGI). Under the first definition - being more advanced - foodstuffs have to be produced, processed and prepared in the designated region. A causal link has to be proven to exist between the regional origin and the quality, which has to be "essentially or exclusively due to a particular geographical environment with its inherent natural and human factors" (Art. 2, Council Regulation No. 2081/1992). The PGI covers a product where at least one of the stages - production, processing, or preparation occurs in the designated area. In a somewhat weaker formulation than for PDOs, quality, reputation or other characteristics are "attributable to that geographical origin" (ibid., Art. 2) for a PGI.
} 
2000, WIRTHGEN 2005], the question under which conditions the generic promotion of regional-origin labelling results in a significant price mark-up for farmers remains largely unanswered. As the second pillar of the EU's CAP aims at strengthening the development of rural areas and providing farmers with diversified opportunities for the marketing of quality products, supporting regional promotion measures of produce from remote locations that feature quality-control systems could be of added significance. Given this background, it is the objective of this paper to provide a methodological framework for the analysis of regional marketing programs which include regional-origin labelling as well as quality assurance and control. An equilibrium-displacement model (EDM) for a segmented market with differential qualities is developed that extends most of the existing approaches in the generic advertising and country-of-origin literature. We investigate the extent to which a phased reduction of initial governmental support levels impacts farmer price premiums and welfare. It could be argued that with increasing producer cost shares for program participation farmers lack the incentive to participate in regional marketing activities that meet a growing consumer demand for high-quality foods from designated regional origins. Results suggest that full governmental support to regional-marketing programs provide significant price mark-ups at the farm level.

Our framework can be applied to a variety of regional marketing programs. An empirical application of the model is illustrated for a selected European case, i.e. "Certified Quality - Bavaria".

\section{Review of Literature}

There is a well-established literature on the economics of generic promotion, starting from classical and general contributions (NERLOVE/WAUGH 1961, FORKER/WARD 1993) to recent and detailed impact analyses applied to selected questions, 
commodities and programs (see the contributions in KAISER 2003). Typically, the economic effects of generic advertising on food demand are statistically modelled and the redistributive and welfare impacts elaborated. Especially for the U.S., where generic advertising is financed by producer levies, cost-benefit ratios are calculated which relate additional revenues and costs for producers due to program participation. Studies have investigated the importance of cross-price effects for advertising effectiveness (KINNUCAN 1996, KINNUCAN/XIAO/HSIA 1996), the distribution of impacts of advertising within the marketing chain (KAISER/SCHMIT 2003) and across interrelated markets (KINNUCAN/MiAo 2000). ZHANG and SEXTON (2002) analyse the implications of market power for the allocative and redistributive effects of generic promotion. Economic studies on European regional promotion programs are rare, but some do exist for Germany (e.g., HofF/ClAES 1997, HERRMANN/THOMPSON/KRISCHIK-BAUTZ 2002).

A broad literature on the economics of food labeling has developed in recent years much of which is surveyed in GOLAN/KUCHLER/MitCHELL (2001). This general literature is related to the theory of food labeling and the role of government in the labelling process. Within this field, regional-origin labelling and especially geographical indications have gained increasing attention among economists as a number of studies reveal high and increasing consumer appreciation for labels of origin in Europe and the U.S. (LUSK et al. 2006, RoOSEN/LUSK/FOX 2003).

In this context a growing literature has focused on the economic impacts of the country of origin applying models of segmented agricultural markets to measure the welfare and market effects of origin labelling (BRESTER/MARSH/ATWOOD 2004). The country-of-origin labelling (COOL) provision of the 2002 U.S. Farm Sector and Rural Investment Act requires from September 30, 2004 that retailers label the country of origin on fresh and frozen foods. Chung, ZHANG and PeEl (2004) review 
studies that have assessed market level costs and welfare effects of introducing COOL in the U.S. meat industry. LUSK and ANDERSON (2004) adapt a WOHLGENANT (1993) equilibrium-displacement model specification of vertically segmented markets to simulate producer and consumer welfare effects of COOL in the U.S. meat industry. Their results reveal that demand increases of two to three percent are sufficient to offset additional costs at the producer level.

Moreover, an extensive literature has investigated the effects of the country of origin as a signal of quality to consumers. BECKER (2002) notes that the regional origin is becoming one of the most important determinants of food demand in the EU. VAN DER LANS et al. (2001) and VERLEGH and STEENKAMP (1999), in a meta-analysis of country-of-origin studies, found origin labels to be a significant factor in consumer product evaluations. Recently, LUSK et al. (2006) differentiate between consumer motivations for origin labels from the economic and marketing literature to investigate the reasons behind "why" consumers want COOL and derive causes for public policy in the U.S.

Despite the numerous extensions in the generic promotion and origin-labelling literature, analyses were mainly carried out within models where one uniform price or cost measure at one stage of the marketing chain is determined. In the case of a regional marketing program that includes regional-origin labelling and additional costs for quality control, as is the case under the EU Council Regulation 2081/1992, different qualities have to be distinguished. Market segmentation occurs between a higher-quality market for the origin-labelled product and an average-quality residual market segment. However, a segmented-market approach that considers the regulations for governmental support of regional origin-labelling set by Council Regulation No. 2081/92 has not yet been developed. For this reason, a flexible approach to evaluating the price and welfare effects of state-financed regional-origin 
marketing programs including quality differentiated products and quality-assurance systems is developed below.

\section{The Model}

The EDM methodology was originally proposed by MUTH (1964) and reviewed by Piggott (1992) and Alston, Norton and Pardey (1995). The objective of the EDM approach applied in this study is to model the producer price and welfare effects and their implications for state-financed regional-origin programs of qualitydifferentiated products and regionally segmented markets.

In our general model each region can produce for a uniform standard-quality market which we call the "mass" market. Each region can also incur additional program participation costs and produce for a high-quality market which is regionally labelled. The demand for these high quality regional products may be augmented by regional promotion expenditures borne within and outside the region.

As stated earlier, a linkage between improved product quality and regional-origin labelling is a justification for government-subsidised promotion efforts. So, we seek a model that will enable us to evaluate promotional programs designed to send quality signals based on regional origin. However, as shown by KINNUCAN (1996), when markets are interrelated, ignoring the cross-price and cross-advertising effects will yield biased measures of advertising effectiveness. Hence, the model explicitly accounts for various cross-price and cross-advertising elasticities. Given the nature of regional-origin labelling, the assumption of perfect product substitutability between "mass" and labeled products from different regions is resolved in favor of a more realistic assumption of differentiated products based on their regional origin and quality. 
We extend the existing work and present a general model which allows for interactions between "mass" and regional-origin markets with respect to price, regional advertising, supply response and differing cost structures.

\subsection{Structure of the Model}

A multi-equation market-equilibrium model for two regions engaged in regionalorigin labelling which are related in price, advertising and costs is specified as

Supply:

$$
S_{j}^{i}=S_{j}^{i}(P, C, Z)
$$

Demand:

$$
D_{j}^{i}=D_{j}^{i}(P, A, X)
$$

Market Equilibrium: $\quad S_{j}^{i}=D_{j}^{i}$,

where $\mathrm{i}=\operatorname{region} \mathrm{A}$ or $\mathrm{B} ; \mathrm{j}=$ mass-market product $\mathrm{M}$, high-quality product $\mathrm{A}$ or $\mathrm{B}$; $\mathrm{P}$ is a vector of producer prices, $\mathrm{A}$ is a vector of regional advertising expenditures, $\mathrm{C}=$ additional producer cost of participation in the regional advertising program, and $\mathrm{Z}$ and $\mathrm{X}$ are exogenous supply and demand shifters. We assume competitive markets at the farm level. Prices and quantities are determined endogenously according to the market equilibrium (3).

We follow the general methods used by KinNUCAN and MYRLAND (2003) and PigGotT (2003), where $d x / x=d \ln x$ is the percentage change of any variable $\mathrm{x}$. Then use of the logarithmic differential approximation to equations (1) - (3) yields the following multi-equation EDM where the parameters are interpreted as elasticities.

\section{Region A}

Supply:

$d \ln S_{M}^{A}=\varepsilon_{M}^{A} d \ln P_{M}+\varepsilon_{M A}^{A} d \ln P_{A}$ 
$d \ln S_{A}^{A}=\varepsilon_{A}^{A} d \ln P_{A}+\beta_{1} d \ln C_{A}$

Demand:

$d \ln D_{M}^{A}=\eta_{M}^{A} d \ln P_{M}$

$d \ln D_{A}^{A}=\eta_{A}^{A} d \ln P_{A}+\eta_{A B}^{A} d \ln P_{B}+\eta_{A M}^{A} d \ln P_{M}+e_{A A}^{A} d \ln A_{A}+e_{A B}^{A} d \ln A_{B}^{A}$

$d \ln D_{B}^{A}=\eta_{B}^{A} d \ln P_{B}+\eta_{B A}^{A} d \ln P_{A}+\eta_{B M}^{A} d \ln P_{M}+e_{B B}^{A} d \ln A_{B}^{A}+e_{B A}^{A} d \ln A_{A}$

\section{Region B}

Supply:

$$
\begin{aligned}
& d \ln S_{M}^{B}=\varepsilon_{M}^{B} d \ln P_{M}+\varepsilon_{M B}^{B} d \ln P_{B} \\
& d \ln S_{B}^{B}=\varepsilon_{B}^{B} d \ln P_{B}+\beta_{2} d \ln C_{B}
\end{aligned}
$$

Demand:

$$
\begin{aligned}
& d \ln D_{M}^{B}=\eta_{M}^{B} d \ln P_{M} \\
& d \ln D_{B}^{B}=\eta_{B}^{B} d \ln P_{B}+\eta_{B A}^{B} d \ln P_{A}+\eta_{B M}^{B} d \ln P_{M}+e_{B B}^{B} d \ln A_{B}+e_{B A}^{B} d \ln A_{A}^{B} \\
& d \ln D_{A}^{B}=\eta_{A}^{B} d \ln P_{B}+\eta_{A B}^{B} d \ln P_{A}+\eta_{A M}^{B} d \ln P_{M}+e_{A A}^{B} d \ln A_{A}^{B}+e_{A B}^{B} d \ln A_{B}
\end{aligned}
$$

\section{Equilibrium Conditions}

$$
\begin{aligned}
& \sum h_{M}^{S i} d \ln S_{M}^{i}=\sum h_{M}^{D i} d \ln D_{M}^{i} \\
& d \ln S_{A}^{A}=h_{A}^{D A} d \ln D_{A}^{A}+h_{A}^{D B} d \ln D_{A}^{B} \\
& d \ln S_{B}^{B}=h_{B}^{D B} d \ln D_{B}^{B}+h_{B}^{D A} d \ln D_{B}^{A}
\end{aligned}
$$

Superscripts denote the region $(A$ or $B$ ), subscripts denote products (mass-quality product $M$, high-quality product $A$, or high-quality labelled product $B), \varepsilon$ 's are ownand cross-price elasticities of supply; $\eta$ 's are own- and cross-price elasticities of demand, $e$ 's are the own- and cross-advertising elasticities, and $C$ 's represent the 
marginal cost of participation for each region ${ }^{2}$. Equilibrium conditions (14) - (16) contain both supply and demand market shares $h_{j}^{S i}$ and $h_{j}^{D i}$, respectively ${ }^{3}$. For instance $h_{A}^{D A}\left(h_{A}^{D B}\right)$ is the market share of the total demand for high-quality product $A$ within region $A(B)$.

As we start from the idea of regional-origin labelling with quality control, this implies vertical product differentiation. Thus, the demand functions of model (4) to (16) do not include a substitutive relationship between the two quality levels. Substitution effects occur at one given quality level only, i.e. between qualities A and B but not between either A or B as opposed to M (KINNUCAN/XIAO/HsiA 1996). There also is substitution on the supply side between the two different qualities. A rising price in the high-quality market leads to a reduction of supply on the lowquality market $\left(\varepsilon_{M A}^{A}<0, \quad \varepsilon_{M B}^{B}<0\right)$.

Given exogenous market shares, advertising quantities, and program-participation cost, the linear equation system (14) - (16) can be solved for the three endogenous price-change variables $d \ln P_{j}$ as,

$$
\left[\begin{array}{l}
d \ln P_{M} \\
d \ln P_{A} \\
d \ln P_{B}
\end{array}\right]=\left[\begin{array}{ccc}
a_{11} & \cdots & a_{13} \\
\vdots & & \vdots \\
a_{31} & \cdots & a_{33}
\end{array}\right]^{-1}\left[\begin{array}{ccc}
b_{11} & \cdots & b_{14} \\
\vdots & & \vdots \\
b_{31} & \cdots & b_{34}
\end{array}\right]\left[\begin{array}{c}
d \ln A_{A}^{A} \\
d \ln A_{B}^{A} \\
d \ln A_{A}^{B} \\
d \ln A_{B}^{B}
\end{array}\right]+\left[\begin{array}{ccc}
a_{11} & \cdots & a_{13} \\
\vdots & & \vdots \\
a_{31} & \cdots & a_{33}
\end{array}\right]^{-1}\left[\begin{array}{ccc}
c_{11} & c_{12} \\
\vdots & \vdots \\
c_{31} & c_{32}
\end{array}\right]\left[\begin{array}{l}
d \ln C_{A}^{A} \\
d \ln C_{B}^{B}
\end{array}\right] \begin{aligned}
& (17) \\
& \text { to } \\
& (19)
\end{aligned}
$$

where the $a$ matrix includes own- and cross-price elasticities of supply and demand as well as market shares, the $b$ matrix captures own- and cross-advertising elasticities, and the $c$ matrix includes parameters associated with the added cost of regional program participation.

\footnotetext{
${ }^{2} \mathrm{We}$ assume the components of $\mathrm{X}$ and $\mathrm{Z}$ are subsumed in the constant terms of equations (1) and (2).

${ }^{3}$ If for supply, $S=S_{M}^{A}+S_{M}^{B}$, then $d \ln S=d \ln S_{M}^{A} \cdot h_{M}^{S A}+d \ln S_{M}^{B} \cdot h_{M}^{S B}$, where $h^{S A}$ and $h^{S B}$ are supply shares on the mass market originating from region $\mathrm{A}$ and $\mathrm{B}$, respectively. This same relationship holds for markets segmented on the demand side.
} 
Parameterisation of the above model is needed to simulate how changes in own- and cross-region advertising expenditures and changes in program participation cost affect market prices, quantities and producer welfare. Empirical illustrations will likely necessitate restrictions to the general model to characterise the unique dimensions of any particular empirical application.

The solution to equation (17) can be used to evaluate the total and distribution of changes in producer welfare due to regional advertising. This can be accomplished by computing changes in producer surplus (PS) in each market, assuming parallel shifts in demand and supply.

$\sum_{i j} \sum_{j} \Delta P S_{j}^{i}=\sum_{i} \sum_{j}\left[p_{j}^{i} S_{j}^{i} \quad d \ln P_{j}^{i}\left(1+0.5 d \ln S_{j}^{i}\right)\right]$.

\subsection{Possible Model Uses}

The model presented above has been designed for a combined analysis of regionalorigin labelling and quality control. Accordingly, the implications of promotion expenditures for the labelled products can be elaborated as well as the consequences of increasing producer costs due to the instruments of quality control. The model allows for the general situation where competing high-quality products exist as well as a common non-competing lower-quality mass product. This is typical for the current situation in the EU where different regional labels have been introduced, e.g., for beef, advertising occurs for competing labels. A crucial task in the empirical application of the model is to define precisely (i) the competing high-quality products and (ii) the relevant market on which the products compete.

If strong competition between high-quality segments of the market does not exist, it would be necessary to restrict the model to distinguish only one regional label from 
the lower-quality market, but perhaps also allow for the possibility of trade between markets. Other problem-specific restrictions can be easily imposed.

The general model may serve other purposes as well. The EDM model could be applied to other relevant issues where market segmentation plays a major role. Cases in point are strategies of country-of-origin labelling, differentiation of ecological as opposed to conventional farming and foods, or the labelling of foods that do not contain genetically modified organisms (GMOs). Some modelling approaches of these markets have already been provided. CHUNG, ZHANG and PEEL (2004), LUSK and ANDERSON (2004) and KinNUCAN and MYRLAND (2005) distinguish between domestic and foreign product market segments in EDMs of vertical supply chains. However, their empirical models do not include cross-price effects between the labelled products. Products from ecological as opposed to conventional farming are analysed in a segmented equilibrium-displacement model by HAGNER (1997) and the impacts of governmental policies on the conventional and ecological markets are elaborated. Moss, ScHMITZ and SCHMITZ (2004) use a partial-equilibrium segregation model in their study of how resistance to the introduction of genetically modified (GM) crops leads to segregated markets for GM and non-GM crops. Based on this model, they illustrate the welfare implications of market segregation and the relevance of segregation costs. To our knowledge the studies of JAMES and ALSTON (2002) and LUSK and NORWOOD (2005) are the only applications of EDMs that explicitly incorporate differentiated product qualities.

Our model differs from these approaches in the literature in two major respects:

1. The modelling framework is applied to regional-origin labelling. None of the other modelling approaches has been used to study this issue. 
2. Although individual papers go further in other respects than we do, none of the segmented-market models in the literature cover competition between highquality products as does our model with labelled goods of regions A and B.

We now provide an application of the model to a regional-labelling and qualitycontrol scheme. The case study is related to the German program "Certified Quality Bavaria".

\section{An Empirical Application}

\subsection{Background}

The origin of Bavarian regional-origin labelling dates back to 1985 when the program "Quality from Bavaria" was established by the Bavarian Ministry for Nutrition, Agriculture and Forestry (for details, see HERRMANN/ThOMPSON/KRISCHIK-BAUTZ 2002). After first used only for seed products and breeding cattle, a program for fed beef was introduced in October 1994, largely influenced by consumer concerns about BSE. To "re-establish and increase confidence of the strongly insecure consumer especially in Bavarian meat" was the declared objective of this program (BSTMELF 1999, p. 10). Advertising for the program occurred in various media and the Bavarian meat-controlling institution, "Bayerische Fleischpruefung e.V.", was responsible for quality and test regulations. Activities under the program were suspended in late 2000 when BSE cases were discovered in Germany.

In accordance with the EU rules on protected designations of origin, a revised program was then started in February 2002: "Certified Quality - Bavaria" (BSTMELF 2002). Participation in the program was open to producers, processors and retailers who agreed to a detailed system of quality control. This requirement is 
binding since the regional label may only be EU-supported when a superior quality is guaranteed.

\subsection{The Bavarian Beef Market}

The general model is specified to characterise the "Certified Quality - Bavaria" program. The model structure consists of two regions (Bavaria and Rest of Germany - ROG), a single high-quality product (produced in Bavaria but sold in both regions) and a common mass-market product (produced in both regions).

\section{Bavaria (Region A)}

Supply:

$$
\begin{aligned}
& d \ln S_{M}^{A}=\varepsilon_{M}^{A} d \ln P_{M}+\varepsilon_{M A}^{A} d \ln P_{A} \\
& d \ln S_{A}^{A}=\varepsilon_{A}^{A} d \ln P_{A}+\beta_{1} d \ln C_{A}
\end{aligned}
$$

Demand:

$$
\begin{aligned}
& d \ln D_{M}^{A}=\eta_{M}^{A} d \ln P_{M} \\
& d \ln D_{A}^{A}=\eta_{A}^{A} d \ln P_{A}+\eta_{A M}^{A} d \ln P_{M}+e_{A A}^{A} d \ln A_{A}
\end{aligned}
$$

\section{Rest of Germany (Region $B$ )}

Supply:

$$
d \ln S_{M}^{B}=\varepsilon_{M}^{B} d \ln P_{M}
$$

Demand:

$$
\begin{aligned}
& d \ln D_{M}^{B}=\eta_{M}^{B} d \ln P_{M} \\
& d \ln D_{A}^{B}=\eta_{A}^{B} d \ln P_{A}+\eta_{A M}^{B} d \ln P_{M}+e_{A A}^{B} d \ln A_{A}^{B}
\end{aligned}
$$

\section{Equilibrium Conditions:}


$\sum h_{M}^{S} \cdot d \ln S_{M}=\sum h_{M}^{D} \cdot d \ln D_{M}$

$d \ln S_{A}^{A}=h_{A}^{D A} \cdot d \ln D_{A}^{A}+h_{A}^{D B} d \ln D_{A}^{B}$

Again, superscripts characterise regions A and B, and subscripts the high-quality product A and the mass product M. Bavaria is the largest exporter of beef among all German federal states. Bavarian exports occur both under the regional label and for unlabelled beef, i.e. for the high-quality and the mass market. Therefore, there is demand for Bavarian beef in the rest of Germany for both qualities (equations (26) and (27)). As exports from the region go to various regional markets in Germany, Bavarian beef competes with beef under various other labels as well as foreign beef. There is no single competitor of regionally-labelled Bavarian beef in the high-quality market sector. Thus, we posit that the labelled product is of superior quality to that of the mass market. We distinguish only the regional label as the high-quality beef product from the mass (lower-quality) beef product.

In the Bavarian case, the high-quality price $\left(\mathrm{P}_{\mathrm{A}}\right)$ is what wholesalers pay producers; it does not include deductions for advertising. The producer contribution to advertising is a cost which must be deducted from $\mathrm{P}_{\mathrm{A}}$ to obtain a net producer price $\mathrm{P}_{\mathrm{P}}$. We derive $\mathrm{P}_{\mathrm{p}}$ from equation (5)

$d \ln S_{A}^{A}=\varepsilon_{A}^{A} d \ln P_{A}+\beta_{1} d \ln C_{A}$,

where

$$
\begin{aligned}
\beta_{1} d \ln C_{A} & =\left(\partial S_{A}^{A} / \partial C_{A}\right)\left(C_{A} / S_{A}^{A}\right) \cdot d C_{A} / C_{A} \\
& =\left(\partial S_{A}^{A} / S_{A}^{A}\right) \\
& =\delta .
\end{aligned}
$$


Here $\delta$ is the relative horizontal shift in the high-quality supply curve due to the added cost of producing high-quality beef. Substituting (30) into (5) yields

$d \ln P_{A}=\left(\frac{1}{\varepsilon_{A}^{A}}\right) d \ln S_{A}^{A}-K$,

where $K=\frac{\delta}{\varepsilon_{A}^{A}}$ is the relative vertical shift in the price direction. Further, the change in producer price $\left(P_{P}\right)$ is defined when $\mathrm{K}=0$ as

$d \ln P_{P}=\left(\frac{1}{\varepsilon_{A}^{A}}\right) d \ln S_{A}^{A}$

and the level of the producer price is given as

$$
P_{P}=P_{M}\left(d \ln P_{P}+1\right) \text {. }
$$

The logic of our comparative-static analysis can be followed by referring to Figure 1. With no advertising (and presumably no higher-quality product) we begin with the high-quality market-equilibrium point $P_{A}^{O}\left(=P_{P}^{O}\right)$ and $Q_{A}^{O}$. Advertising expenditures shift demand outwardly to $\mathrm{D}^{1}$ with a new equilibrium point $P_{A}^{l}\left(=P_{P}^{l}\right)$ and $Q_{A}^{l}$. With advertising cost fully provided by the government, the producer price $\left(P_{P}^{1}\right)$ exactly equals the wholesale price $\left(P_{A}^{1}\right)$ and positive producer-welfare gains are realised. However, with producer contributions to the cost of advertising, the supply-function shifts to $\mathrm{S}^{1}$ yielding the new equilibrium point at quantity $\left|Q_{A}^{2}\right|$ corresponding to wholesale and producer prices of $\left|P_{A}^{2}\right|$ and $\left|P_{P}^{2}\right|$, respectively. At this point, $P_{A}^{2}-P_{P}^{2}=\delta$ (or producer cost). Supply could shift leftward as producer costs $(\delta)$ increase to such a degree that the welfare gains to producers become negative. In terms of our model the quantity and price changes are $d \ln S_{A}^{A}, d \ln P_{A}$ and $d \ln P_{P}$. 


\section{Figure 1: High-Quality Beef Market}

\subsection{Parameterisation}

Not all parameters of the empirical model are readily available. Nor do we have complete information on the market segments of labelled and non-labelled products as well as reliable price data in the market segments or the additional producer costs due to participation in a program that combines quality standards and control with regional-origin labelling. However, there is much we do know. For instance, we have good statistical estimates of the responsiveness of labelled-product sales to advertising effort. Given this somewhat limited knowledge, simulations and sensitivity analyses are particularly important. Simulations can also be used to illustrate stronger changes of policy than those realised in the past. This is crucial when one is interested in the amount of additional advertising expenditures necessary to induce a defined price difference between the labelled and the non-labelled market.

Table 1 provides the parameters and elasticities of the empirical model. A key parameter of the model for evaluating the impacts of advertising for a regional-origin label is the advertising elasticity of demand. We take the econometric estimate of 0.04 by Herrmann, THOMPSON and Krischik/BAUTZ (2002) measured for the program "Quality from Bavaria". It is consistent with most studies from the genericpromotion literature that the advertising elasticity of demand is significantly positive but typically less than 0.1 . In this same study, econometric estimates of the own-price elasticities of demand (-0.8 in the high-quality segment and -0.4 on the "mass" market) were found to be consistent with other estimates for beef demand in Germany. With respect to the importance of cross-price effects on the welfare implications of regional-origin promotion, the cross-price elasticity of demand 
between high quality and "mass" quality beef is 0.1 . Some recent econometric studies based on demand systems indicate that our price and cross-price elasticities might be at the lower end, suggesting that the price elasticity of demand for beef has increased over time and might now be above unity (WILDNER 2000).

Market simulation results can be particularly sensitive to both the advertising elasticities as well as the marginal cost of participation parameter. Given an advertising elasticity of 0.04 in both markets, we focus attention over the sensitivity of the market impacts of the cost parameter $(\delta)$. The price and quantity change effects are extended to producer welfare effects in each market segment.

\section{Table 1: Parameters and Elasticities of the Empirical Model}

\subsection{Simulations}

Our benchmark simulations are based on actual segmented-market data for the year 2003. At that time, the mass-quality price $\left(P_{M}\right)$ averaged 2.31 . While high-quality certified Bavarian product price premium over the mass-market product varied considerably, the premium achieved could be as much as ten percent. In Bavaria, the annual production of labelled and mass market beef was 107,608 and 161,413 million kgs., respectively. We assume that there exists no competing regional-quality label in any state of ROG. In the ROG, no high-quality labelled beef was produced. However, the production of mass-market beef was 1,160,523 kgs. Thus, the market shares of mass-market beef produced in Bavaria and ROG were 12 and 88 percent, respectively. Our benchmark assumes the existence of an ongoing promotion program in Bavaria which implies that the producer cost of participation are included in the existing supply function for the labelled product. Thus, shifts in the supply function are due to producer contributions associated with promotional labelling. In 
our simulations from the baseline, we explore the effects of a 100 percent increase in the promotional expenditures for Bavarian quality-labelled beef.

In Table 2 we show how increased regional quality advertising affects prices and quantities in the segmented markets and how these change as producers share the cost of advertising with the government. Suppose the situation is that the regional labelling of "Certified Quality - Bavaria" is subsidised by 100 percent governmental payments $(\delta=0)$. This is especially likely for the year 2003 where the regional quality label was revised by the EU commission and launched on the market ${ }^{4}$. Since that time, governmental support was scheduled to be reduced by $10 \%$ per year.

\section{Table 2: Price and Quantity Effects of Increased Advertising of High-Quality Bavarian Beef}

The simulated advertising-induced outward demand shift increases both the wholesale price of Bavarian beef $\left(\mathrm{P}_{\mathrm{A}}\right)$ and the producer price $\left(\mathrm{P}_{\mathrm{P}}\right)$. Market interrelationships reveal that advertising Bavarian beef has a positive influence on the mass-market price. When the cost parameter $\delta=0$, all costs associated with the advertising-induced demand shift are borne by the government. In this situation, both the wholesale and producer price in the high-quality Bavarian market increase by 4.1 percent over the mass-market price. The positive supply response of the high-quality Bavarian product shifts the mass-market supply leftward in Bavaria, while the marginally higher $\mathrm{P}_{\mathrm{M}}$ encourages a small positive supply response in the ROG mass market.

4 Annual Bavarian advertising expenditure on "Certified Quality - Bavaria" for beef was 0.5 million Euro in 2003. Total program expenditures of the state of Bavaria in 2003 were 2.556 million, which includes advertising expenditures for other products and program costs. 
Notwithstanding increased wholesale prices for the Bavarian high-quality product, as producers are asked to share in the cost of advertising ( $\delta$ increases), net producer price falls as the cost-induced supply function shifts leftward. Producer contributions act as a wedge between wholesale and producer prices. This wedge can increase until the added advertising cost exactly equals the benefits. This breakeven point is where the benefit-cost parameter $|\alpha|=1.0$ and the increase in $\mathrm{P}_{\mathrm{A}}$ is 8.0 percent. Different changes in $\mathrm{P}_{\mathrm{A}}$ and $\mathrm{P}_{\mathrm{P}}$ are observed as the breakeven point $(\alpha)$ moves "up or down" in Table 2.

Changes in producer surplus (PS) associated with the promotion of "Certified Quality - Bavaria" are shown in Table 3. Clearly, the overall change in producer surplus is greatest when the demand shift is entirely government subsidised $(\delta=0)$. However, for the profit-maximising producer, it makes sense to share in the cost of advertising because positive changes in PS continue as producers contribute up to a breakeven point, again where $\alpha=1.0$; that is, where the change in producer surplus is zero. Also, producers are expected to contribute as scheduled government subsidies decrease. The breakeven point increases when the advertising contribution of the Bavarian producers rises.

\section{Table 3: Changes in Producer Surplus due to Increased Advertising of High- Quality Bavarian Beef (millions of )}

Welfare changes among markets also occur. Advertising of the Bavarian high-quality product in both regions (Bavaria and ROG) results in positive welfare changes in all markets and regions. Even the ROG gains from Bavarian advertising albeit small. In fact, due to substitutability in supply, the mass-market welfare gain in ROG is relatively greater than thatin the Bavarian mass market. Since the absolute sizes of 
the markets differ we calculated producer-surplus changes per beef farmer. For the participants of "Certified Quality - Bavaria" the actual number of participating beef producers in 2003 is used to calculate PS of "label members". Of course, the change in PS is greatest in the "no cost" situation, where $\delta=0$. The last column in Table 3 shows the sum of the high-quality and mass-market effects for Bavaria. On a perfarm basis clear gains to advertising are seen even as producers share in the cost of advertising. Note that these are changes in producer surplus, so it is profitable for producers to contribute to the advertising effort up to the point where $\triangle P S=0$.

\section{Concluding Remarks}

Quality signals of regionally produced products can be economically beneficial to producers. The benefits accrued are directly related to the effectiveness to which the demand for the high-quality product can be augmented with advertising, the cost associated with the advertising effort and, of course, the basic economic structural characteristics of the market segments under study.

Policy conclusions arise from the analysis. Quality control for regional products and regional-origin labelling are supposed to raise the income of farmers in rural areas and, thus, contribute to rural development. A pre-condition is that the income effect of rising demand outweighs that of increasing costs due to participation in the new programme. These results are based on computed benefit-cost ratios of regionalorigin labelling from the producers' point of view. Additional analyses are needed as to whether policies are successful under an extended regional objective function that includes changes in consumer surplus and additional regional expenditures for the labelling scheme. More research is necessary, too, regarding the aggregate assessment of regional-origin labelling from the federal or national point of view. 
In this paper we suggest a general economic framework that can be used to examine problems of this nature. We illustrate this framework with an empirical examination of the "Certified Quality - Bavaria" promotion program. This illustration includes two regions, Bavaria and Rest of Germany (ROG), both of which produce beef for the mass-market but only Bavaria produces the higher quality-labelled product of pure guaranteed Bavarian origin. We allow for trade in both products between regions.

The promotion of the Bavarian labelled product in Bavaria positively influences both regions and products. All market segments can gain. While clearly producer gains are great when the cost of the advertising the Bavarian labelled product is financed entirely by the government, it remains rational for profit-maximising producers to cofinance contributions as well.

We found our proposed analytical framework to be a flexible and easy-to-use tool to simulate market behaviour in response to promoting the Bavarian quality-labelled product. We believe it is generally applicable to examine a number of policy-related issues in segmented commodity markets.

\section{References}

Alston, J.M., G. Norton and P.G. PARdey (1995), Science Under Scarcity:

Principles and Practice for Agricultural Research Evaluation and Priority Setting. Ithaca, NY, Cornell University Press.

BALLING, R. (2000), Ergebnisse von Verbraucherbefragungen zur Bedeutung der regionalen Herkunft von Lebensmitteln. In: Dachverband Agrarforschung (ed.), Regionale Vermarktungssysteme in der Land-, Ernährungs- und Forstwirtschaft. (Agrarspektrum, Vol.30), Frankfurt: Verlagsunion Agrar, pp.19-37. 
BECKER, T. (2002), Bedeutung und Nutzung geschützter Herkunftszeichen. Gutachten im Rahmen des TA-Projektes „Entwicklungstendenzen von Nahrungsmittelangebot und -nachfrage und ihre Folgen“" - Vertiefungsphase, vorgelegt dem Büro für Technikfolgenabschätzung (TAB) beim Deutschen Bundestag, 15.12., Stuttgart, Berlin.

Brester, G.W., J.M. MARSh and J.A. AtwoOD (2004), Distributional Impacts of Country-of-Origin Labeling in the U.S. Meat Industry. "Journal of Agricultural and Resource Economics”, Vol. 29, No. 2, pp. 206-227.

BSTMELF, Bayerisches Staatsministerium für Ernährung, Landwirtschaft und Forsten (Hrsg.) (1999), Regionale Vermarktung von Agrarprodukten und Lebensmitteln: Voraussetzungen, Strategien und Maßnahmen in Bayern, Dokumentation, RB-Nr. 08/99/22, Muenchen.

BSTMELF, Bayerisches Staatsministerium für Ernährung, Landwirtschaft und Forsten (Hrsg.) (2002), „Geprüfte Qualität - Bayern“, Zeichensatzung RB-Nr. 08/02/07, Muenchen.

Chung, C., T. Zhang and D.S. PeEL (2004), Will Country-of-Origin Labeling (COOL) be "Cool" for the U.S. Meat Industry? Paper presented at the American Agricultural Association Meeting (AAEA), August 1-4, Denver, CO.

Commission OF THE EU (1992), Council Regulation (EEC) No. 2081/92 of 14 July 1992 on the Protection of Geographical Indications and Designations of Origin for Agricultural Products and Foodstuffs. "Official Journal of the European Communities", L208, 24/07, pp. 1-8.

COMMISSION OF THE EU (2001), Community Guidelines for State Aid Advertising of Products Listed in Annex I to the EC Treaty and of Certain Non-Annex I Products (2001/C 252/03). “Official Journal of the European Communities”, C252, 12/09, pp. $5-14$. 
FORKER, O.D. and R.W. WARD (eds.) (1993), Commodity Advertising: The Economics and Measurement of Generic Programs. New York: MacMillan.

Golan, E. F. KuChLER and L. Mitchell (2001), Economics of Food Labeling. “Journal of Consumer Policy”, Vol. 24, No. 2, pp. 117-184.

HAGNER, C. (1997), Akzeptanz und wohlfahrtsökonomische Analyse von Extensivierungspolitiken in Deutschland - unter besonderer Berücksichtigung des ökologischen Landbaus. (Schriften des Zentrums für regionale Entwicklungsforschung der JLU Gießen, Bd. 70), Giessen, Germany.

HerRmanN, R., S.R. THOMPSON and S. KRISCHIK-BAUTZ (2002), BSE and Generic Promotion of Beef: An Analysis for "Quality from Bavaria". “Agribusiness - An International Journal”, Vol. 18, No. 3, pp. 369-385.

Hoff, K. and R. ClaEs (1997), Der Einfluss von Skandalen und Gemeinschaftswerbung auf die Nachfrage nach Rindfleisch: Eine ökonometrische Analyse. „Agrarwirtschaft (German Journal of Agricultural Economics)“, Vol. 46, No.10, pp. 332-344.

JAmeS, J.S. and J.M. ALSton (2002), Taxes and Quality: A Market-Level Analysis. "The Australian Journal of Agricultural and Resource Economics", Vol. 46, No. 3, pp. $417-445$.

KAISER, M. (2003), Distribution of Benefits and Costs of Commodity Check-Off Funded Programs. “Agribusiness - An International Journal”, Vol. 19, No. 3, pp. 273-275.

KAISER, M. and T.M. SCHMIT (2003), Distributional Effects of Generic Dairy Advertising Throughout the Marketing Channel. “Agribusiness - An International Journal”, Vol. 19, No. 3, pp. 289-300. 
KInNUCAN, H.W. (1996), A Note on Measuring Returns to Generic Advertising in Interrelated Markets. "Journal of Agricultural Economics", Vol. 47, No. 2, pp. 261-267.

KINNUCAN, H.W. and Y. MIAO (2000), Distributional Impacts of Generic Advertising on Related Commodity Markets. “American Journal of Agricultural Economics", Vol. 82, No. 3, pp. 672-678.

KinnuCAN, H.W. and Ø. MYRLAND (2003), Free-Rider Effects of Generic Advertising: The Case of Salmon. “Agribusiness - An International Journal”, Vol. 19, No. 3, pp. 315-324.

KinnuCAN, H.W. and Ø. MYrLAND (2005), Effects of Income Growth and Tariffs on the World Salmon Market. “Applied Economics”, Vol. 37, No. 17, pp. 1967-1978. KinNuCAN, H.W., H. XIAO and C.J. HSIA (1996), Welfare Implications of Increased US Beef Promotion. “Applied Economics”, Vol. 28, pp. 1235-1243.

LUSK, J.L. and J.D. ANDERSON (2004), Effects of Country-of-Origin Labeling on Meat Producers and Consumers. "Journal of Agricultural and Resource Economics", Vol. 29, No. 2, pp. 185-205.

LuSK, J.L. and F.B. NORWOOD (2005), Modeling Beef Quality Heterogeneity. “Journal of Agricultural and Applied Economics", Vol. 37, No. 3, pp. 603-618.

Lusk, J.L., J. BRown, M. TYLER, P. IDLIR, R. THOMPSON and J. WELSH (2006), Consumer Behavior, Public Policy and Country-of-Origin Labeling. "Review of Agricultural Economics", Vol. 28, No. 2, pp. 284-292.

Moss, C.B., T.G. SchMITZ and A. SchMiTZ (2004), The Brave New World: Imperfect Information, Segregation Costs, and Genetically Modified Organisms. "German Journal of Agricultural Economics (Agrarwirtschaft)", Vol. 53, No. 8, pp. 303308. 
Muth, R.F. (1964), The Derived Demand for a Productive Factor and the Industry

Supply Curve. "Oxford Economic Papers", Vol. 16, No. 2, pp. 221-234.

Nerlove, M. and F. WAugh (1961), Advertising without Supply Control: Some Implications of a Study of the Advertising of Oranges. "Journal of Farm Economics", Vol. 43, No 4, pp. 813-837.

PiggotT, N.E. (2003), Measures of Precision for Estimated Welfare Effects for Producers from Generic Advertising. "Agribusiness - An International Journal”, Vol. 19, No. 3, pp. 379-391.

PIgGOTt, R.R. (1992), Some Old Truths Revisited. "Australian Journal of Agricultural Economics”, Vol. 26, No. 2, pp. 117-140.

Roosen J., J.L. LuSK and J.A. Fox (2003), Consumer Demand for and Attitudes Toward Alternative Beef Labeling Strategies in France, Germany, and the UK. “Agribusiness - An International Journal”, Vol. 19, No. 1, pp. 77-90.

VAN DER LANS, I.A. and M.L. Antonella De CiCCO (2001), The Role of the Region of Origin and Certificates of Origin in Consumer Evaluation of Foods. "European Review of Agricultural Economics", Vol. 28, No. 4, pp. 451-477.

VERLEGH, P.W.J and J.-B.E.M. STEENKAMP (1999), A Review and Meta-Analysis of Country-of-Origin Research. "Journal of Economic Psychology", Vol. 20, pp. $521-546$.

WILDNER, S. (2000), Die Nachfrage nach Nahrungsmitteln in Deutschland unter besonderer Berücksichtigung von Gesundheitsinformationen. Sonderhefte der Agrarwirtschaft Nr. 169, Agrimedia, Holm.

Wirthgen, A. (2005), Consumer, Retailer, and Producer Assessments of Product Differentiation According to Regional Origin and Process Quality. "Agribusiness - An International Journal", Vol. 21, No. 2, pp. 191-211. 
Wohlgenant, M.K. (1993), Distribution Gains from Research and Promotion in Multi-Stage Production Systems: The Case of the U.S. Pork and Beef Industries.

“American Journal of Agricultural Economics”, Vol. 75, No. 3, pp. 642-651.

ZhANG, M. and R.J. SeXTON (2002), Optimal Commodity Promotion when

Downstream Markets are Imperfectly Competitive. “American Journal of Agricultural Economics", Vol. 84, No. 2, pp. 352-365. 
Figure 1: High-Quality Beef Market

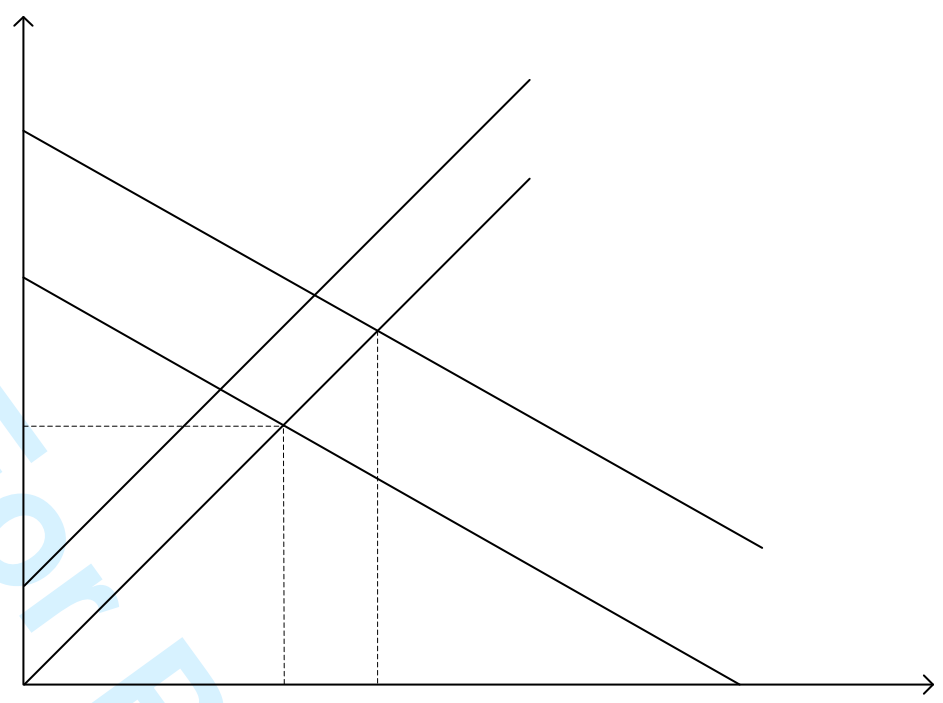


ERROR: invalidaccess

OFFENDING COMMAND: --filter--

STACK:

/LZWDecode

- filestream-

$\left[\begin{array}{lllllll}56 & 0 & 0 & -174 & 0 & 174\end{array}\right]$

true

174
56

- savelevel - 